\title{
Evaluation of Acetaminophen Effect on Oxidative Stressed Mice by Peroxide Hydrogen
}

\author{
BENKHASSI Zoubair ${ }^{1}$, LAHLOU Fatima Azzahra ${ }^{1, *}$, HMIMID Fouzia ${ }^{1}$, LOUTFI Mohammed ${ }^{1}$, \\ BENAJI Brahim ${ }^{2}$, BOURHIM Noureddine ${ }^{1}$
}

\author{
${ }^{1}$ Biochemistry and Molecular Biology laboratory, Ain Chock Faculty of Science Hassan II University, Casablanca, Morocco \\ ${ }^{2}$ Microbiology pharmacology Biotechnology and Environment laboratory, Ain Chock Faculty of Science Hassan II University, \\ Casablanca, Morocco \\ *Corresponding author: lahloufz@hotmail.fr
}

Received June 25, 2013; Revised July 26, 2013; Accepted August 02, 2013

\begin{abstract}
Acetaminophen (Paracetamol) is among the most commonly used analgesic and antipyretic drugs worldwide, it's often, but anomalously, classified as non-steroidal anti-inflammatory drugs (NSAIDs) in textbooks of pharmacology $[1,2]$. This study aims to evaluate if paracetamol has an antioxidant effect, relative to its analgesic antipyretic and weak anti-inflammatory activities, or it possesses a cytotoxic potential. Oxidative stress was induced by intraperetoneal injection of peroxide hydrogen $\left(\mathrm{H}_{2} \mathrm{O}_{2}\right)$, and then a comparative study is made concerning the activities of the antioxidant enzymes SOD, CAT, and GR as well as lipid peroxidation levels in liver. An increase in SOD, CAT, GR activity and lipid peroxidation in mice treated with $\mathrm{H}_{2} \mathrm{O}_{2}$ accompanied by paracetamol; compared to the group treated by vitamin $\mathrm{C}+\mathrm{H}_{2} \mathrm{O}_{2}$ showed that acetaminophen doesn't show any antioxidant effect. Moreover this study has suggested that acetaminophen induced cytotoxicity in liver mediated by increased oxidative stress and altered redox metabolism.
\end{abstract}

Keywords: acetaminophen (paracetamol), peroxide hydrogen, oxidative stress

Cite This Article: BENKHASSI Zoubair, LAHLOU Fatima Azzahra, HMIMID Fouzia, LOUTFI Mohammed, BENAJI Brahim, and BOURHIM Noureddine, "Evaluation of Acetaminophen Effect on Oxidative Stressed Mice by Peroxide Hydrogen.” American Journal of Biomedical Research 1, no. 4 (2013): 75-79. doi: 10.12691/ajbr-1-4-2.

\section{Introduction}

Acetaminophen (paracetamol) is an effective, cheap, and widely available analgesic; it's classified as non steroidal anti-inflammatory drugs (NSAIDs), because it possesses analgesic activity against pain of mild to moderate severity but has few anti-inflammatory properties.

Acetaminophen, unlike NSAIDs, has only a weak inhibitory effect on purified preparations of cyclooxygenase (COX)-1 and COX-2 at therapeutic concentrations, it has been believed that the target of acetaminophen is a "brainspecific" COX enzyme that produces prostaglandins in the central nervous system thereby initiating fever and pain [3]. Thus it is a major cause of liver failure; it has been shown that high doses of the analgesic drug acetaminophen (APAP) produce centrilobular liver necrosis in human and other susceptible species $[4,5,6]$. Although the precise mechanism is still not determined, oxidative stress has been suggested to be involved in hepatotoxicity by APAP.

Oxidative stress is known as a disturbance of homeostasis between rate of antioxidant defenses and the rate of reactive oxygen species (ROS). These reactive species are products of regular cell metabolism $\left({ }^{1} \mathrm{O}_{2}\right.$ : singlet oxygen, $\mathrm{H}_{2} \mathrm{O}_{2}$ : hydrogen peroxide, $\mathrm{OH}^{*}$ hydroxyl radical, $\mathrm{O}_{2} \cdot$ : superoxide radical). However in low levels they are indispensable in many biochemical processes, including intracellular messaging in such us: apoptosis [7] immunity [8], and defense against micro-organisms [9,10]. A number of enzymes are known to have major antioxidant activity, such as superoxide dismutase (SOD), catalase (CAT), glutathione peroxidase (GPX) and glutathione reductase (GR). Antioxidants can be defined as any substance that when present at low concentrations compared to that of an oxidizable substrate, significantly delays or inhibits the oxidation of that substrate [11,12]. Therefore SOD detoxified $\mathrm{O}_{2}^{\circ}$, CAT reduces $\mathrm{H}_{2} \mathrm{O}_{2}$ and GR catalyzes the NADPH-dependent regeneration of glutathione (GSH) from the oxidized form (GSSG) generated by GPX.

In view of the widespread availability of paracetamol we sought to examine the effect of paracetamol in a stressed mouse. We hypothesised that administration of this drug following stress induction by hydrogen peroxide would reduce or increase liver oxidant stress

\section{Materials and Methods}

\subsection{Tests}

The test concerned 30 males adult Swiss albino mice weighting 25-30 grams. They were acclimatized to 
laboratory conditions before the test and fed ad libitum. They were fasted 16 hours prior to the treatment [13].

All experiments were in accordance with the guidelines provided by the CPCSEA.

Animals were divided into 6 groups as it's resumed in Table 1. Paracetamol was first administered intraperitoneally for a month, then according to [14] $\mathrm{H}_{2} \mathrm{O}_{2}$ was injected 30 $\mathrm{mn}$ before sacrifice, where we achieved higher levels of ROS generated by $\mathrm{H}_{2} \mathrm{O}_{2}$ treatment during that incubation time.

Table 1. summary table of doses treatment with paracetamol and hydrogen peroxide

\begin{tabular}{|c|c|c|c|}
\hline Groups & $\begin{array}{c}\text { Number } \\
\text { of mice }\end{array}$ & Treatment & Dose \\
\hline 1 & 4 & $\mathrm{NaCl}$ & $0.9 \%$ \\
\hline 2 & 4 & Paracetamol & $30 \mathrm{mg} / \mathrm{kg}$ \\
\hline 3 & 4 & Paracetamol $+\mathrm{H}_{2} \mathrm{O}_{2}$ & $30 \mathrm{mg} / \mathrm{kg}+1.5 \mathrm{~g} / \mathrm{kg}$ \\
\hline 4 & 4 & Vitamin C & $500 \mathrm{mg} / \mathrm{kg}$ \\
\hline 5 & 4 & Vitamin C $+\mathrm{H}_{2} \mathrm{O}_{2}$ & $500 \mathrm{mg} / \mathrm{kg}+1,5 \mathrm{~g} / \mathrm{kg}$ \\
\hline 6 & 4 & $\mathrm{H}_{2} \mathrm{O}_{2}$ & $1.5 \mathrm{~g} / \mathrm{kg}$ \\
\hline
\end{tabular}

\subsection{Tissue Preparation for Analytic Procedures}

Livers were rapidly thawed and manually homogenized, using a Potter homogenizer (Elvehjem) with a glass pestle, in 3 volumes of ice-cold $10 \mathrm{mM}$ HEPES, $1 \mathrm{mM}$ EDTA, $0.25 \mathrm{M}$ Sucrose and $10 \mathrm{mM}$ 2-mercaptoethanol, $\mathrm{pH}$ 7.4. All procedures were performed on ice. Homogenates were centrifuged at $2000 \mathrm{xg}$ for $60 \mathrm{mn}$ at $4^{\circ} \mathrm{C}$ (sigma 2-16K) and the resultant supernatants were aliquoted and stored at $-20^{\circ} \mathrm{C}$ for later enzyme assays

\subsection{Chemicals}

All biochemicals were obtained from Sigma (St. Louis, MO), Roche Diagnostics (Mannheim, Germany), or BioRad Laboratories (Hercules, CA). All the other chemicals were purchased from Merck (Darmstadt, Germany) and all other chemicals were of analytical grade

\subsection{Biochemical Assays}

All assays were conducted at $25^{\circ} \mathrm{C}$ using a spectrophotometer (Thermo electron corporation, Biomate 3).

\subsubsection{Catalase}

The consumption of $7.5 \mathrm{mM} \mathrm{H}_{2} \mathrm{O}_{2}$ in $50 \mathrm{mM}$ potassium phosphate buffer ( $\mathrm{pH} \mathrm{7)}$ was monitored at $240 \mathrm{~nm}$ as indicated in [15].

\subsubsection{Glutathione Reductase}

The assay of [16] was used. The assay mixture contained $0.5 \mathrm{mM}$ oxidized glutathione, $1 \mathrm{mM}$ EDTA, 0.1 $\mathrm{mM}$ NADPH and $50 \mathrm{mM}$ potassium phosphate buffer $(\mathrm{pH}$ 7.4) and NADPH consumption was monitored at $340 \mathrm{~nm}$.

\subsubsection{Superoxide Dismutase}

The enzyme was assayed according to [17] with assay conditions: $5 \mathrm{mM}$ EDTA, $2.5 \mathrm{mM} \mathrm{MnCl}_{2}, 0.27 \mathrm{mM}$ $\mathrm{NADH}, 3.9 \mathrm{mM}$ 2-mercaptoethanol in $50 \mathrm{mM}$ potassium phosphate buffer ( $\mathrm{pH} 7$ ), monitored at $340 \mathrm{~nm}$. The decrease in absorbance is measured after the addition of $\mathrm{NADH}$ to $0.27 \mathrm{mM}$ as final concentration.

\subsubsection{Thiobarbutiric Acid Reactive Substances}

Lipid peroxidation was estimated by the formation of thiobarbituric acid reactive substances (TBARS) and quantified in terms of malondialdehyde (MDA) equivalents according to the method described by [18]: 1 $\mathrm{ml}$ of samples was added to $1 \mathrm{ml}$ solution $(0.375 \%$ thiobarbituric acid and $15 \%$ trichloracetic acid in $0.25 \mathrm{M}$ hydrochloric acid). The tubes were heated at $100^{\circ} \mathrm{C}$ during $15 \mathrm{~min}$ and they were cooled in the ice to stop the reaction. One then carries out a centrifugation with $1000 \mathrm{xg}$ during $10 \mathrm{~min}$. The reading of supernatant was made to $535 \mathrm{~nm}$.

\subsubsection{Protein Assay}

Protein content was measured according to the Bradford procedure [19] by using bovine serum albumin (BSA) as standard. Protein reagent was added to protein solutions. The absorbance was measured at $595 \mathrm{~nm}$ after $10-15 \mathrm{mn}$ of incubation in the dark.

\subsubsection{Enzyme Activity Expression}

The specific activity of each enzyme was calculated using the following formula:

$\mathrm{AS}=(\Delta \mathrm{Abs} / \mathrm{mn} \times 1000) /(\varepsilon \times[\mathrm{P}] \mathrm{x} \mathrm{Ve})$

$\Delta$ Abs/mn: absorbance variation/minute

$\varepsilon$ (extinction coefficient) :

$\varepsilon\left(\mathrm{H}_{2} \mathrm{O}_{2}\right)=40 \mathrm{M}-1 . \mathrm{cm}-1$, for CAT

$\varepsilon(\mathrm{NADH})=6220 \mathrm{M}-1 . \mathrm{cm}-1$, for SOD and GR

$\varepsilon($ MDA-TBA complex $)=153000 \mathrm{mM}-1 . \mathrm{cm}-1$, for MDA

[P]: protein concentration

Ve: assay volume

\subsection{Statistical Analysis:}

All values were expressed as mean \pm standard error of mean and the statistical significance between treated and control groups were analyzed by means of Student's t-test. $\mathrm{P}<0.05$ was considered significant.

\section{Results and Discussion}

\subsection{Monitoring of Body Weight in Mice}

According to Figure 1, the body weight of all treated mice showed slight variations but weren't significantly different from those of the control, except mice treated with $\mathrm{H}_{2} \mathrm{O}_{2}$. They show a significant weight loss showing a low activity during treatment period. Many toxicity studies (repeated dose of $\mathrm{H}_{2} \mathrm{O}_{2}$ ) indicated a decreased body weight gain in animal studies (i.e., at dose levels of $50-500 \mathrm{mg} / \mathrm{kg} /$ day in rats) as well as changes in blood chemistry parameters $[20,21]$. 


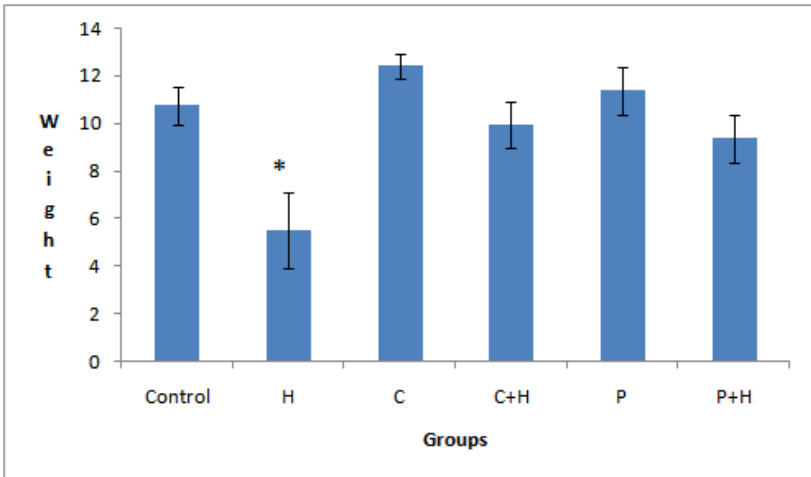

Figure 1. weight gain in grams during 30 days of treatment $\mathrm{H}_{2} \mathrm{H}_{2} \mathrm{O}_{2}$, C: Vitamin $\mathrm{C}, \mathrm{C}+\mathrm{H}$ : Vitamin $\mathrm{C}+\mathrm{H}_{2} \mathrm{O}_{2}$, P: Paracetamol, P+H: Paracetamol $+\mathrm{H}_{2} \mathrm{O}_{2}$ *significantly different from control at $\mathrm{P}^{<} 0.05$. The number of mice used in each group was 4

\subsection{Determination of the Enzymatic Activity of Antioxidants}

According to Figure 2, Figure 3, Figure 4 and Figure 5 catalase, superoxide dismutase, gluthation reductase activity and the MDA level were found to be significantly raised $(\mathrm{P}<0.05)$ in group 6. This indicates that these indicators of oxidative stress status were reactive inside the liver cell and were potentially utilized for counteracting the harmful effects of $\mathrm{H}_{2} \mathrm{O}_{2}$.

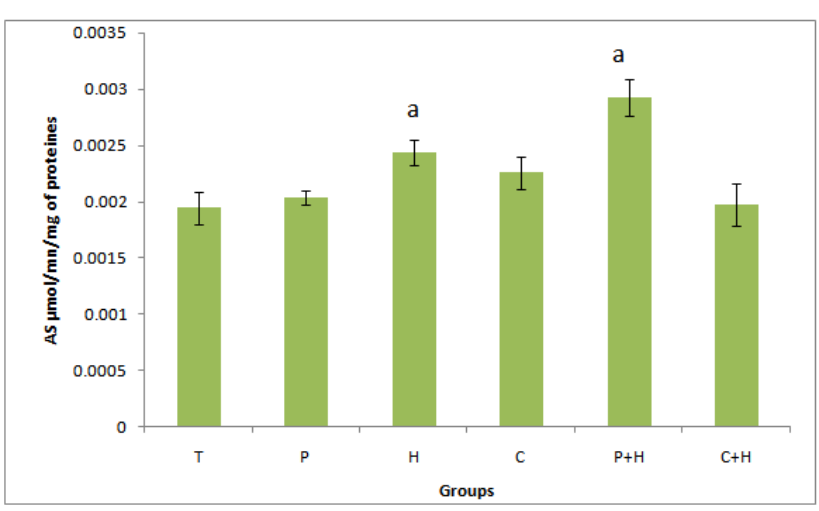

Figure 2. Oxidative stress evaluated by Gluthation reductase activity, T: control, $\mathrm{H}: \mathrm{H}_{2} \mathrm{O}_{2}$, C: Vitamin C, $\mathrm{C}+\mathrm{H}$ : Vitamin $\mathrm{C}+\mathrm{H}_{2} \mathrm{O}_{2}$, P: Paracetamol, $\mathrm{P}+\mathrm{H}$ : Paracetamol $+\mathrm{H}_{2} \mathrm{O}_{2}$ a significantly different from control at $\mathrm{P}^{<} 0.05$. The number of mice used in each group was 4

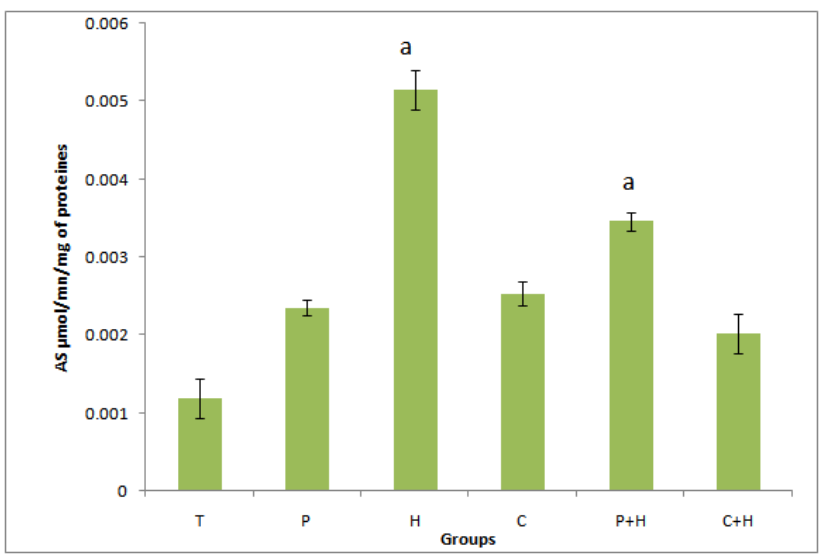

Figure 3. Oxidative stress evaluated by SOD activity, T: control, $\mathrm{H}$ : $\mathrm{H}_{2} \mathrm{O}_{2}$, C: Vitamin C, C+H: Vitamin $\mathrm{C}+\mathrm{H}_{2} \mathrm{O}_{2}$, P: Paracetamol, $\mathrm{P}+\mathrm{H}$ : Paracetamol $+\mathrm{H}_{2} \mathrm{O}_{2}$ a significantly different from control at $\mathrm{P}^{<} 0.05$. The number of mice used in each group was 4

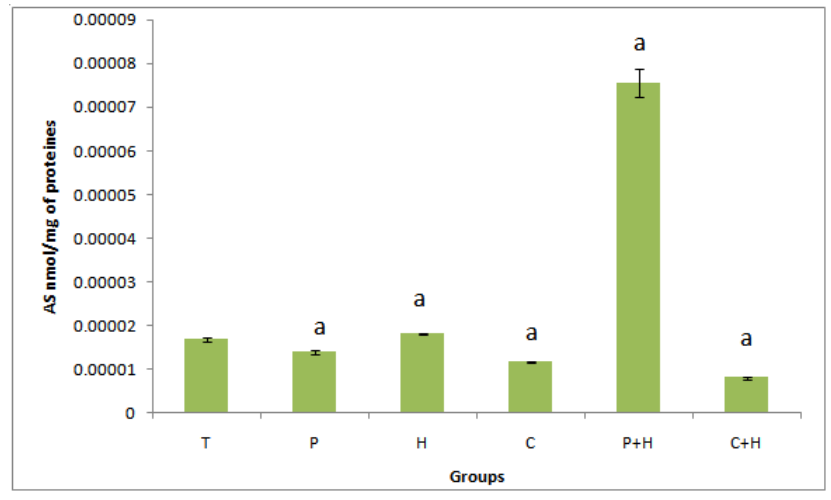

Figure 4. Oxidative stress evaluated by MDA level, T: control, $\mathrm{H}_{2} \mathrm{H}_{2} \mathrm{O}_{2}$, C: Vitamin C, C+H: Vitamin $\mathrm{C}+\mathrm{H}_{2} \mathrm{O}_{2}$, P: Paracetamol, $\mathrm{P}+\mathrm{H}$ : Paracetamol $+\mathrm{H}_{2} \mathrm{O}_{2}$ a significantly different from control at $\mathrm{P}^{<} 0.05$. The number of mice used in each group was 4

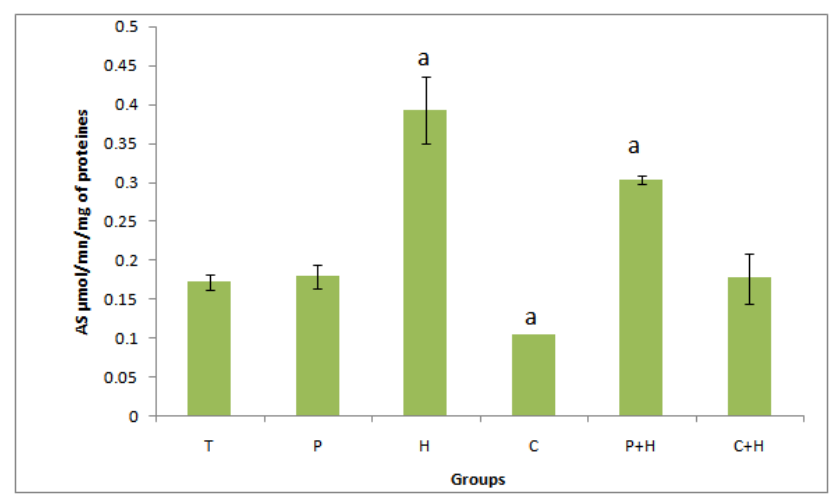

Figure 5. Oxidative stress evaluated by CAT activity, T: control, $\mathrm{H}$ : $\mathrm{H}_{2} \mathrm{O}_{2}$, C: Vitamin C, C+H: Vitamin $\mathrm{C}+\mathrm{H}_{2} \mathrm{O}_{2}$, P: Paracetamol, $\mathrm{P}+\mathrm{H}$ : Paracetamol $+\mathrm{H}_{2} \mathrm{O}_{2}$ a significantly different from control at $\mathrm{P}^{<} 0.05$. The number of mice used in each group was 4

Superoxide dismutases (SOD) are a group of metalloenzymes that protect cells from superoxide radicals by catalyzing the dismutation of the superoxide radical to molecular $\mathrm{O}_{2}$ and $\mathrm{H}_{2} \mathrm{O}_{2}$. The main function of SOD is to scavenge $\mathrm{O}_{2}$ radicals generated in various physiological processes, thus preventing the oxidation of biological molecules, either by the radicals themselves, or by their derivatives [22]. In the present study, the highest activity was seen in mice treated with $\mathrm{H}_{2} \mathrm{O}_{2}$ (group 6) followed by $\mathrm{P}+\mathrm{H}$ (group 3) (Figure 3). Elevated SOD activity indicates the production of higher levels of ROS generated by $\mathrm{H}_{2} \mathrm{O}_{2}$ and paracetamol treatment which in turn triggered the elevated SOD expression in the cells. Control, paracetamol, vitamin $\mathrm{C}$ and vitamin $\mathrm{C}+\mathrm{H}_{2} \mathrm{O}_{2}$ showed comparatively lower activity. In the case of vitamin $\mathrm{C}+$ $\mathrm{H}_{2} \mathrm{O}_{2}$ the activity was much lower which suggest that vitamin $\mathrm{C}$ was able to counter the $\mathrm{H}_{2} \mathrm{O}_{2}$ effects with reduced need for higher SOD expression.

To counter the potential hazards of intracellular $\mathrm{H}_{2} \mathrm{O}_{2}$, which freely diffuses into cells and oxidizes cell membranes, proteins, and DNA [23], most organisms possess catalase (CAT), a high-molecular-weight, hemecontaining protein whose primary function is to counter $\mathrm{H}_{2} \mathrm{O}_{2}$, leaving $\mathrm{O}_{2}$ and water as by-products [24]. In the present research the highest activity was observed in the $\mathrm{H}_{2} \mathrm{O}_{2}$ treatment, followed by Paracetamol $+\mathrm{H}_{2} \mathrm{O}_{2}$. This indicates the active role of CAT in modulating the harmful effects of $\mathrm{H}_{2} \mathrm{O}_{2}$. Interestingly, this also directly correlated to high SOD activity. Lowest CAT activity was observed in the case of vitamin $\mathrm{C}$, while Vitamin $\mathrm{C}+\mathrm{H}_{2} \mathrm{O}_{2}$ was 
much lower (Figure 5) indicating again the beneficial role of vitamin $\mathrm{C}$ in quenching free radicals.

Malondialdehyde (MDA) is one of the most frequently used indicators of lipid peroxidation [25]. The production of hydroxyl radical and other powerful radicals can initiate a chain reaction of lipid peroxidation in which polyunsaturated fatty acids are converted into lipid peroxides. Increased MDA can be interpreted as resulting from cellular membrane damage initially caused by increased formation of radicals [26]. In the present study, higher MDA content was observed at groups treated with paracetamol $+\mathrm{H}_{2} \mathrm{O}_{2}$ indicating higher levels of lipid peroxidation. However the other groups showed lower MDA content indicating the normal membrane deterioration process (Figure 4). Given that MDA is considered as a valuable indicator of oxidative damage of cellular components, our results suggest that paracetamol and $\mathrm{H}_{2} \mathrm{O}_{2}$ treatment enhanced reactive oxygen species generation in the liver and that antioxidant defenses were not totally able to effectively scavenge them which was the case in group treated with vitamin C.

The role of GR is fundamental for GPX activity, maintaining the cytosolic concentration of reduced glutathione [27,28], and therefore involved in detoxification reactive oxygen. Peroxidases decompose hydrogen peroxide and organic hydroperoxides produced during normal metabolism and also prevents peroxideinduced DNA damage, lipid peroxidation, and protein degradation [29]. In this work, Mice treated with Paracetamol and $\mathrm{H}_{2} \mathrm{O}_{2}$ showed the highest activity of gluthatione reductase followed by $\mathrm{H}_{2} \mathrm{O}_{2}$ alone treatment. However other groups showed lower activity (Figure 2).

Results obtained in this study can be explained by the fact that APAP (N-acetyl-p-aminophenol) by CYP (cytochrome P450) leads to the formation of N-acetylpbenzoquinoneimine (NAPQI), a highly reactive intermediate metabolite [30], which is normally detoxified by conjugation with reduced glutathione (GSH). This may explain the highest activity of GR observed in mice treated with paracetamol $+\mathrm{H}_{2} \mathrm{O}_{2}$ (Figure 2).

Oxidative stress is also considered to be involved in the induction of hepatotoxicity by APAP. The one electron oxidation of APAP by CYPs may generate reactive oxygen species (ROS). Hydrogen peroxide and superoxide are produced during metabolic activation of APAP in the mixed function oxidase system [31,32,33].

These results have clearly suggested that acetaminophen induced hepatotoxicity by increased oxidative stress demonstrated by the high pool of antioxidant enzymes (CAT, GR and SOD), plus MDA level. Therefore paracetamol didn't show any protective effect when combined with $\mathrm{H}_{2} \mathrm{O}_{2}$ (group3), however the redox imbalance was more altered, indicated by pronounced peroxidation and higher rate of antioxidant enzymes activity. These data also confirmed the protect effect of vitamin C, a known antioxidant that acts by scavenging free radicals molecules with one or more unpaired electrons and transform them to stable molecules.

In conclusion acetaminophen should be used carefully in order to prevent hepatotoxicity, induced by oxidative damage and redox imbalance. This toxicity can be initiated by the metabolic activation of APAP to NAPQI, a reactive metabolite, ROS generation and subsequent lipid peroxidation during APAP biotransformation.

\section{Acknowledgments}

This project was supported by the National Center of Scientific Research; the authors would thank them for their generous funds.

\section{References}

[1] Brunton, L.L, Lazo, J.S, Parker, K.L, Buxton, I.L.O, Blumenthal, $\mathrm{D}$, Analgesic-antipyretic and anti-inflammatory agents: pharmacotherapy of gout, Hardman J.G, Limbrid L.E (eds), Goodman and Gilman, The Pharmacological Basis of Therapeutics, New York, 2005.

[2] Rang, H.P, Dale, M.M, Ritter, J.M, Moore, P, Pharmacology, Churchill Livingstone, London, 2006.

[3] Botting, R.M, "Mechanism of action of acetaminophen: is there a cyclooxygenase 3?” Clin Infect Dis, 31.202-210.2000.

[4] Ruepp, S.U., Tonge, R.P., Shaw, J., Wallis, N. and Pognan, F, "Genomics and proteomics analysis of acetaminophen toxicity in mouse liver”, Toxicol Sci, 65.135-150.2001.

[5] Sumioka, I., Matsura, T. and Yamada, K, “Acetaminophen induced hepatotoxicity: Still an important issue”, Yonago Acta Med, 47.17-28.2004.

[6] Aleksunes, L.M., Campion, S.N., Goedken, M.J. and Manautou, J.E, "Acquired resistance to acetaminophen hepatotoxicity is associated with induction of multidrug resistance-associated protein 4 (Mrp4) in proliferating hepatocytes”, Toxicol Sci, 104.261-273.2008.

[7] Ghosh, J. and Myers, C.E, "Inhibition of arachidonate 5lipoxygenase triggers massive apoptosis in human prostate cancer cells”, Proc Natl Acad Sci, 95.13182-13187.1998.

[8] Yin, G.Y., Yin, Y.F. and He, X.F, "Effect of zhuchun pill on immunity and endocrine function of elderly with kidney-yang deficiency”, Chung Kuo Chung Hsi I Chieh Ho Tsa Chih, 15.601603.1995.

[9] Bae, Y.S., Kang, S.W., Seo, M.S., Baines, I.C., Tekle, E., Chock, P.B. and Rhee, S.G, "Epidermal growth factor (EGF)-induced generation of hydrogen peroxide”, J Biol Chem, 272.217-221.1997.

[10] Lee, Y.J., Galoforo, S.S., Berns, C.M., Chen, J.C., Davis, B.H., Sim, J.E., Corry, P.M. and Spitz, D.R, "Glucose deprivationinduced cytotoxicity and alterations in mitogen-activated protein kinase activation are mediated by oxidative stress in multidrugresistant human breast carcinoma cells", J Biol Chem, 273.52945299.1998.

[11] Percival, M., “Antioxidants”, Clin Nutr, 31.1-4.1998.

[12] Young, I.S. and Woodside, J.V, "Antioxidants in health and disease”, J Clin Pathol, 54.176-186.2001.

[13] Zentella de Pina, M., Sandoval-Montiel, A., Serrano-Alessandri, L., Montalvo-Jave, E., Zentella-Dehesa, A. and Pina, E, "Ethanolmediated Oxidative Changes in Blood Lipids and Proteins Are Reversed by Aspirin-like Drugs", Archi Med Res, 38.269275.2006.

[14] Lahlou, F.Z., Hmimid, F., Loutfi, M. and Bourhim, N, "Antioxidant response of Camellia sinensis and Rosmarinus officinalis aqueous extracts toward $\mathrm{H}_{2} \mathrm{O}_{2}$ stressed mice”, J Appl Pharm Sci, 2.70-76.2012.

[15] Aebi, H., “Catalase in vivo”, Methods Enzymol, 105.121-126.1984

[16] Di Ilio, C., Polidoro, G., Arduini, A., Muccini, A. and Federici, G, "Glutathione peroxidase, Glutathione reductase, gluthatione Stransferase and gamma_glutamyl transpeptidase activities in the human early pregnancy placenta”, Biochem Med, 29.143-148. 1983.

[17] Paoletti, F., Aldinucci, D., Mocali, A. and Carparrini, A, "A sensitive spectrophotometric method for the determination of superoxide dismutase in tissue extracts”, Anal Biochem, 154.526541.1986.

[18] Samokyszyn, V.M. and Marnett, L.J, "Inhibition of liver microsomal lipid peroxidation by 13-cis-retinoic acid”, Free Radic Biol Med, 8.491-496.1990.

[19] Bradford, M., "A rapid and sensitive method for the quantitation of microgram quantities of protein utilizing the principle of protein dye binding”, Anal Biochem, 72.248-254.1976.

[20] Agency for Toxic Substances and Disease Registry (ATSDR), Tox FAQs TM for Hydrogen Peroxide. U.S Department of Health and Human Services, Public Health Service, April 2002. 
[21] European Commission Joint Research Centre (ECJRC), European Union Risk Assessment Report, Hydrogen peroxide. 2nd Priority List, Volume.38. Report by the European Commission Joint Research Centre, Luxembourg, 2003.

[22] Liebmann, J., Fisher, J., Lipschultz, C., Kuno, R. and Kaufman, D.C, "Enhanced glutathione peroxidase expression protects cells from hydroperoxides but not from radiation or doxorubicin", Cancer Res, 55.4465-4470.1995.

[23] Gonzalez-Flecha, B. and Demple, B, "Metabolic sources of hydrogen peroxide in aerobically growing Escherichia coli”, $J$ Biol Chem, 179.13681-13687.1995.

[24] Brown, S.M., Howell, M.L., Vasil, M.L., Anderson, A.J. and Hassett, D.J, "Cloning and characterization of the katB gene of Pseudomonas aeruginosa encoding a hydrogen peroxide-inducible catalase: purification of katB, cellular localization, and demonstration that it is essential for optimal resistance to hydrogen peroxide", J Bacteriol, 177. 6536-6544.1995.

[25] Nielsen, F., Mikkelsen, B.B., Nielsen, J.B., Andersen, H.R. and Grandjean, P, "Plasma malondialdehyde as biomarker for oxidative stress: reference interval and effects of life-style factors", Clin Chem, 43.1209-1214.1997.

[26] Niedernhofer, L.J., Daniels, J.S., Rouzer, C.A., Greene, R.E. and Marnett, L.J, "Malondialdehyde a product of lipid peroxidation, is mutagenic in human cells”, J Biol Chem, 278.31426-31433.2003.
[27] Tian, W.N., Braunstein, L.D., Apse, K., Pang, J., Rose, M., Tian, $\mathrm{X}$. and Stanton, R.C, "Importance of glucose-6-phospahate dehydrogenase activity in cell death”, Am J Physiol, 276.11211131.1999.

[28] Leopold, J.A. and Loscalzo, J, “Cyclic strain modulates resistance to oxidant stress by increasing G6PDH expression in smooth muscle cells”, Am J Physiol, 279.2477-2485.2000.

[29] Bierl, C., Voetsch, B., Jin, R.C., Handy, D.E. and Loscalzo, J, "Determinants of human plasma glutathione peroxidase (GPx-3) expression”, J Biol Chem, 10.107-122.2004.

[30] Dahlin, D.C., Miwa, G.T., Lu, A.Y.H. and Nelson, S.D, "NAcetylp- benzoquinone imine: a cytochrome P-450-mediated oxidation product of acetaminophen", Proc Natl Acad Sci, 81.1327-1331.1984.

[31] Nordblom, G.D. and Coon, M.J, "Hydrogen peroxide formation and stoichiometry of hydroxylation reactions catalyzed by highly purified liver microsomal cytochrome P-450”, Arch Biochem Biophys, 180.343-347.1977.

[32] Kuthan, H., Tsuji, H., Graf, H. and Ullrich, V, "Generation of superoxide anion as a source of hydrogen peroxide in a reconstituted monooxygenase system”, FEBS Lett, 91.343345.1978.

[33] De Vries, J., "Hepatotoxic metabolic activation of paracetamol and its derivatives phenacetin and benorilate: oxygenation or electron transfer?” Biochem Pharmacol, 30 .399-402.1981. 